\title{
The Role of Madrasah Supervisor in Sustaining Management of Quality Madrasah Aliyah
}

\author{
Mulyawan Safwandy Nugraha \\ Department of Islamic Education \\ STAI Sukabumi \\ West Java, Indonesia \\ mulyawan77@yahoo.co.id
}

\author{
Ai Rohayani \\ MAN 1 Kota Sukabumi \\ Sukabumi West Java, Indonesia
}

\begin{abstract}
The management and sustaining of Madrasah Aliyah (Formal Islamic Senior High School) in Indonesia sometimes the Madrasah Supervisors find it not easy to carry out their responsibility accurately and diligently as prescribed by the process of achieving the laid down goals. The main aim of this study is to assess the general roles of Supervisor in sustaining and management of quality and efficiency of Supervisor's roles in Madrasah Aliyah. The purpose of this paper is to examine the key roles of Supervisor's play in providing quality education in Madrasah Aliyah as already stated, Supervisors solve many problems in terms of sustaining and maintaining schools catabolic. The roles of Supervisor is to improve the quality of competencies of the principals and teachers. The principal in meeting these inverse issues were also examined as the chief executive who manages the school finance and who can use his ingenuity to raise fund to complement government's efforts, provision and maintenance of physical facilities, principal as a curriculum monitor and instructional supervisor do consider himself as a good model to be emulated with an element of dynamisms that can observed drastically motivator and quick change facilitator. Effective instructional delivery and maintenance of standards in the school system are enhanced through regular checking both internal and external supervision of the school and must be fully concerned with the physical environment and other facilities around the school corners. The supervisor owes it a duty to modify the attitude of the staff and motivate them to put in their best at achieving educational goals. However, it includes the roles of discipline both academic and non-academic staffs performance and adherence of schools rules and regulations with zeal for accepting open doors for other organizations that willing to assists the schools.
\end{abstract}

Keyword-Supervisor, Sustaining, Management, Quality, Madrasah Aliyah

\section{INTRODUCTION}

Educational change abounds and nowhere is this more noticeable than in the transformation of many schools into learning organizations. [1][2] Less obvious, however, are the implications this transformation holds for the helping force termed "educational supervision". For those educators whose role responsibilities include teacher supervision, there is a need to understand this person-oriented process in a setting emphasizing empowerment, needs satisfaction and role effectiveness.

Efforts to improve the quality of education is a topic that is always current. The quality of education is a necessity and also demands fundamental to achieving educational goals.
Without the weight and quality of education, efforts to educate the nation and develop human resources fully difficult to achieve. Quality education is critical in preparing qualified human resources in the future. Madrasah is one institution that is able to produce quality human, then the provision of education, especially in Madrasah Aliyah must be supported by Human Resources (HR) quality, dedicated, creative and innovative in the face of changing times, so it goes well according with the system and the applicable rules. The availability of qualified human resources in the organization of education, of course, will bring Madrasah Aliyah easier to achieve the goals set.

Madrasah Aliyah is one of the formal educational institutions whose position is equivalent to senior high school (SMA). In the Regulation of the Minister of Religious Affairs Number 90 of 2013 on the Management Standards Madrasah mentioned in article 1 that the Madrasah Aliyah hereinafter, abbreviated MA, is formal education unit which organizes public education with the peculiarities of Islamic religion in secondary education as a continuation of the junior high schools, junior, or other forms equal, the same or equivalent recognized Junior High School or MTs (Madrasah Tsanawiyah).

In the theory of management, supervision is an attempt to ensure the planning and implementing done correctly. In the context of improving the quality of education in Madrasah, the supervision has a strategic role. Madrasah Supervisors shall have supervision competence, because among its duties is to conduct academic supervision of the teacher.

The success of the implementation of quality education are closely linked to the success of increasing the competence and professionalism of Teachers and Education Personnel without ignoring other factors such as infrastructure and financing. Supervisors is one of the educational personnel whose position holds a significant and strategic role in improving the professionalism of teachers and principals, as well as the quality of education in schools.

Supervision is school supervisor in preparing a monitoring program, carry out the surveillance program, carried out the evaluation results of the implementation of the surveillance program, and implement guidance and professional training of teachers and principals. Indonesian Government Regulation 
No. 74 Year 2008 on Teachers in Article 15 paragraph (4) explained that the school supervisor must conduct the academic and managerial oversight. Thus, the school supervisor is required to have adequate qualifications and competence to be able to carry out its supervisory duties in a professional manner.

Professional Trustees is school supervisor's conducting academic and managerial oversight and guidance activities and professional training of teachers and principals to the optimum. In addition, to increase the professionalism of the school supervisor professional development should be carried out in order to answer the challenges of increasingly complex world of education and to better guide the school towards the achievement of national education goals that are effective, efficient, and productive.

Given the important role of madrasah supervisors in advancing the quality of national education, the demands and responsibilities that should be owned by the school supervisor also be great as well.

This paper explores The Role of Madrasah Supervisor in Sustaining Management of Quality Madrasah Aliyah In West Java Indonesia to identify about Educational supervision programs, Mechanical implementation of educational supervision, supervision of the implementation process of the education and follow-up the implementation of the regulatory supervision of madrasah education conducted in Madrasah Aliyah West Java, Indonesia.

\section{LITERATURE REVIEW}

Kimball Wiles [3] states that "Supervision is assistance in the development of a better teaching-learning situation". Supervision is the process help to improve teaching and learning situation for the better. This understanding shows that supervision is a process of assistance, guidance and coaching supervisors or teachers to improve the learning process. This formulation suggests that supervision services covering the whole teaching and learning situation (goal, material, technique, method, teacher, student, an environment). Learning situations that should be improved and enhanced services through supervision activities.

Thus the supervision services covering all aspects of the organization of education and teaching. The concept of supervision cannot be equated with the inspection. This is because the concept of inspection is more emphasis on power and are likely to be authoritarian. The supervision is more about friendship and kinship based on the delivery of services and better cooperation among teachers, because it is democratic.

In the process of education, supervision or supervision is an integral part in improving learning achievement and the quality of madrasah. So the supervision of education is nothing but a business providing services to education stakeholders, especially teachers, either individually or in groups in an attempt to improve the quality of learning process and results.
The supervision activities include the determination of the conditions or terms of personnel and material needed for the creation of effective teaching and learning situation, and meets the requirements of the business. According [4] that specifically supervision programs include (1) helping teachers individually and in groups in solving the problem of teaching; (2) to coordinate all the efforts of teaching into educational behaviors that are well integrated; (3) conducting a continuous training program for teachers; (4) promoting quality tools and sufficient for learning; (5) generate enthusiasm and motivate strong teachers to achieve maximum performance; (6) establish a good relationship and cooperation between schools, social agencies and the relevant agencies and the public.

In essence supervision contains several main activities, namely continuous coaching, professional development of personnel, improvement of teaching and learning situation, with the final target achievement of educational goals and personal growth of students. In other words, there is a process under supervision services for assisting or fostering teachers. This formation led to the improvement or upgrading professional skills of teachers, and then later transferred to the teaching behavior and thus creating a situation of teaching and learning more effective and ultimately to improve the achievement of learners. So understanding more focused supervision attempt to provide service and assistance, either individually or in groups in an attempt to improve the teaching, so that teachers and other education personnel feel the guidance of a supervisor and not as a relationship between superiors and subordinates but a human relationship.

Supervision of education is an engineering services whose main purpose to learn and improve together factors that affect the growth and development of children. Businesses that can be done in the implementation of supervision is to arouse and stimulate the spirit of teachers and other school officials, trying to conduct and complete the scientific equipment and establish good cooperation and harmony between teachers, students, and other school officials. Meanwhile, according to Alfonso (1981) that the supervision of teaching is an act of official conduct designed by the institution that directly affect the behavior of teachers in a variety of ways to help student learning and to achieve the objectives undertaken by the institution.

\section{RESEARCH METHODOLOGY}

It is qualitative and naturalistic in nature with a case-study approach, trying to obtain holistic research results with deepinsights. The data, either emic or etic, were obtained from two teachers (Ade Anshorullah from MAN 1 Sukabumi and Heni Nurhaeni from MA Sunanul Huda Cisaat Sukabumi), a principal of Madrasah Aliyah (Pahirudin), a Madrasah Supervisor (Tris Mediansyah) by taking ideas of the management of quality madrasah aliyah in West-Java Jndonesia.

The research was located in Kabupaten Sukabumi West Java, through the observation of The role of madrasah supervisor in 
sustaining/management of quality madrasah aliyah in West Java Indonesia related to the madrasah Aliyah as an important target and the centre for the study called the "extreme case" [5] as the meeting points of a research pattern of a case-study. Then, in the research gradual steps were also taken namely: 1) classifying symptoms in detail; 2) examining proper media for observation; 3) categorizing the functions of the symptoms; 4) making planning of sampling to have a proper target; 5) determining codes to be consistently applied; and 6) making data analysis. And the procedures of data collection were observations, interviews, coding, naming, data management and interpretation.

In this present research, a qualitative design using a linear combination of data from files, units, or from the organization of the research location was employed. Merriam suggests that researchers always relate facts and the facts are always processed during the research. They always manage the data into folders of indexes, files, and then they are analyzed manually. Then the data organization is accompanied by analyzing the data continuously to obtain insights and interpretation as a whole.

\section{RESULT AND DISCUSSION}

\section{A. Education Supervision Program}

The results of the research can be revealed that the supervisor together with the teachers arrange supervision programs according to the needs in the field. This as told by Tris Mediansyah as madrasah supervisor in KAbupaten Sukabumi that "during this time I have put together a program in writing and guide the implementation of our activities guide, nurture, guide teachers, identify problems, solve problems to improve the competency of teachers".

The program drawn up by supervisors in carrying out supervision include: annual program supervisor, lattice / indicators supervision, and collecting process data early potential resources, analyzing the results of learning / coaching students. Develop grating in order to formulate questions, conduct comprehensive analysis, providing direction, giving an example of execution of tasks, giving advice to professional advancement, prepared a report on the supervision, monitoring and guiding the implementation of the Evaluation and Remedial.

The interview with Pahirudin (The Principal of MAN 1 Sukabumi) stated that the preparation of the supervision program has involved various related elements in it. Preparation of supervision programs conducted at the beginning of each semester of the school year, with the involvement of the madrasah supervisor (Tris Mediansyah) assigned by the Ministry of Religious Affairs Kabupaten Sukabumi West Java, principal, the deputy headmaster, senior teachers and representatives of the Council working group Subject Teacher (MGMP) on end of each semester of the current year evaluation supervision program with the aim to determine the extent of such programs has been realized and the activities that need to be revised because it is not relevant to be implemented. Likewise to identify things that can hinder the process of educational supervision. Furthermore, the findings of the evaluation of both the program and the results of the supervision of the implementation of immediate action to meet the targets set in the pre-defined.

Results of interviews with Tris Mediansyah as Madrasah Supervisor revealed that the targets madrasah education supervision program is any religious teachers, subject teachers, with the aim of fostering teachers to be more skilled and competent in performing the task in addition, it is also to be more optimal curriculum implementation. Targets in the implementation of the supervision of the education of the teacher is the professional capabilities of teachers, namely the supervision of academic education that includes learning clicking teach them the mastery of teaching materials by teachers, learning approach, the use of media learning, student engagement and evaluation in the process of learning and other objectives are the administrative process of learning teach that the administrative aspects as supporting the implementation of the teaching and learning process in-among them the syllabus, the semester program, the annual program, plan teaching programs and books support used.

\section{B. Supervision of Engineering Education}

The results showed that the observation technique classes are not conducted on all teachers to be supervised, because not enough time in doing so, the techniques of classroom observation only do the teachers that should require further development because of limited knowledge, shortcomings and weaknesses in mastery classes and teachinglearning unpleasant methods. The results of the observation will be discussed with the teacher to be followed up and held improvements in the future.

The results of interviews with teachers (Ade Ashorullah and Heni Nurhaeni) mention that in the past semester I do classroom observation by a supervisor, I was nervous all. He noticed all the aspects that I teach, materials, methods, interaction with students and the media that I use. Once out of the classroom, given the direction that I'm doing it quite right, he explains about the weaknesses that I have while providing direction and ways to correct. I am satisfied and committed to rectify any weaknesses

To find out what is done by the teacher and how it did affect the learning process in the classroom, the most appropriate method to do is visit the class. The results of interviews with Tris Mediansyah as a Madrasah Supervisor explained through classroom visits teachers are assisted see clearly the problems encountered, to critically analyze and encourage them to find alternative solutions. Classroom visits as a tool for encouraging teachers to improve the way teachers teach and the way students learn. Classroom visits can give teachers the opportunity to express his experience as well as an attempt to provide a sense of capable teachers.

\section{Process of Educational Supervision}

In accordance with the program that has been planning at the beginning of each semester of the current year, the intensity of supervision adjusted to the schedule that has 
already been agreed. The results of interviews with teachers, noted that the intensity of the supervision of the implementation of more frequent although not on the same teacher. Sometimes being a supervisor is the headmaster, on other occasions as supervisor is from the Office of Religious Affairs in Sukabumi. In this semester, I've just had a turn supervised.

Results of interviews with Tris Mediansyah as a Madrasah Supervisor also provide information that supports the data presented by the teacher. A visit to Madrasah Aliyah is more often done even if not every month can be present, as many madrasahs must-see, unless there are problems that need solving immediately. Furthermore, keep coordinating with the headmaster in implementing educational supervision.

The interview with Pahirudin as a Principal in MAN 1 Sukabumi mentioned that the implementation of the supervision of a previously scheduled regular supervision of the implementation schedule presented at the beginning of the semester each academic year. The schedule also included in the supervision and implementation of the target to be supervised. Implementation of educational supervision activities for the first semester is often done in August to October, while for the second semester conducted in February to April each year subjects.

Based on the results of research in the learning process a number of aspects / indicators were observed, namely 1) pre-learning process, 2) the core activities of learning is mastery of the subject matter, approach / learning strategies, use of learning resources / media of learning, learning triggers and watching-out of a discipline students, assessment processes and outcomes of learning and the use of good language, (3) the cover is to reflect on a summary by involving students and to implement follow-up by giving directives on the activities of the task as part of remedial/enrichment.

\section{Follow-up Supervision of Education}

In the implementation of supervision prescribed many weaknesses and deficiencies in the learning process, especially the preparation and administration of the learning process. The results of interviews with Tris Mediansyah as a Madrasah Supervisor said that when performed supervision of education, there are still teachers who are not yet ready with a lesson plan (RPP), in addition, sometimes there is a teacher who did not master the lessons, no props and only use the lecture method, so the need for further guidance and direction after the learning process of learning takes place.

The interview with Pahirudin as a Principal in MAN 1 Sukabumi, said that the implementation of supervision bring a positive effect to the teacher in the learning process, namely: 1) Teachers become passionate, more confident and more either to know themselves and develop the personnel privacy ability, (2 ) become more capable in realizing professional expertise, (3) promote deeper awareness of the needs of the students and enlarge their competencies to meet those needs through education and teaching effort that it provides. In addition, we also found concerns the teachers themselves, including inefficient, lackluster, and difficult to adjust and frustrating.

In the process of learning found many difficulties by the teacher. Based on this research, it is known that the findings of supervision of education that needs to be followed up include (a) the difficulty of teachers in preparing a learning device, (b) difficulties in learning activities with learning models, (c) difficulty in mastering the material difficult, (d) difficulties in creating the creativity of student learning, (e) difficulties in class management, (f) the difficulties in the use of effective learning methods, ( $g$ ) the difficulty in changing the conventional ways of teaching. This constraint is a major factor facing the task of madrasah teachers and supervisors in order to nurture and guide the trouble it becomes an easy job.

\section{DISCUSSION}

\section{A. Education Supervision Program}

The first step to achieving a success on achieving a goal begins with the preparation of the program. Programming is part of the management process has a very important meaning. Similarly, the supervisor in the supervision of education in Madrasah Aliyah in West Java, Indonesia, ideally madrasah supervisor arrange short-term program, arrange term and long term aimed in improving the quality of education. Before carrying out the supervision of a teacher must first develop its program by having a clear formulation both the ends and the means necessary, as proposed by [6], namely: Should have a formulation of clear planning and contain activities aimed at improving the effectiveness and the results to the learning process.

Supervision programs are activities that are designed such that the supervisor has a program that allows them to control an ongoing basis. Based on the plan of action, supervisors can set out the steps to be taken, how to perform supervisory tasks, controlling and evaluating its performance. [7] explains that the work program is an indicator of the ability of supervisors to carry out the task and at the same as a measuring tool to determine whether a supervisor can understand the work. Supervisor as educators, have the ability to back-up the work program. Supervisors can make planning, organizing, the implementation of the program and conduct an evaluation to determine the effectiveness of the work.

Supervision programs not only supervision schedule, format and instrument ratings supervision. But more than that supervision programs include an analysis of the ability of teachers, research and development of learning process, fostering the ability of teachers and curriculum development analysis.

Based on the results of this research revealed that prior to supervise the education of the teacher, the supervisor has compiled the program and guide the implementation of activities. Preparation of educational supervision program conducted at the beginning of the semester each year lesson involving the deputy headmaster, teachers, seniors and groups MGMPs. 


\section{B. Supervision of Engineering Education}

Efforts to help improve and develop the potential resources to be implemented with a variety of tools and techniques of supervision. John Minor [8] explains that: Generally the tools and techniques of supervision of education can be divided into two kinds of techniques that individual, which is a technique implemented by a teacher individually and techniques that are groups, which is a technique that is done to serve more than one person.

Research results revealed that the engineering supervision done by supervisors at Madrasah Aliyah in West Java is a class observation techniques, personal conversations and classroom visits. Through classroom observation, supervisors can observe the actual teaching and learning situation. Observations occurred in close and be able to assess the competence of teachers as a whole, from the way teachers teach, provide materials, managing a classroom, dress, speak out. So that the positive effect on student learning objectives.

Sahertian states that Objective observations to obtain data that is as objective as possible so that the material obtained can be used to analyze the difficulties faced by teachers in improving teaching and learning things. For the teacher's own data analyzed, will help to change the ways of teaching to a better direction. For students of course could lead to a positive influence on the learning progress.

After classroom observations carried out, followed by a private conversation (individual conference), which is a private conversation between a supervisor with a teacher. In that conversation both in terms of trying to see how good teaching, which is entrusted with the efforts to solve the problems faced by teachers.

The results showed that the activities of group supervision, such as education and training, teacher meetings, discussions, workshops and seminars not do. In terms of activities as it was very important to provide insight and competence development of teachers. Supervision techniques used so can not reveal the weaknesses of teacher learning process in detail. In addition, the development and coaching of teachers in the group is not performing well. Whereas the activities of the group can solve the problems faced by teachers together.

\section{Process of Educational Supervision}

Implementation of the supervision of the teacher, the primary duty Madrasah Supervisor, but not all teachers can be supervised by the headmaster or the number of madrasahs being trained supervisors. It caused unavailability of time and comparison of the number of teachers with a supervisor, so it cannot embraced all teachers. For that need to be involved deputy headmaster, senior teacher of teachers MGMPs in the implementation of educational supervision.

The process of supervising the implementation of the Madrasah Aliyah in West Java is done in several stages, meeting before observation, teaching and teacher observation meeting after observation. Burhanuddin states the implementation of the supervision is done in three steps, namely the stage of preliminary meeting activities, classroom observation phase (teachers who are teaching and feedback gathering phase).

Supervision carried out on the basis of teachers' needs and not the needs of headmaster or supervisor. For that at the stage of preliminary meetings headmaster and supervisors to discuss teaching ability to be improved by the teacher, determined its aspects, subsequently agreed on by the teacher and supervisor. Implementation of supervision at this preliminary stage requires a supervisor tips in creating a pleasant atmosphere, a family atmosphere, fairness and warmth.

Classroom observation is the second step in the stage of supervision. Classroom observations are needed by the supervisor. Sahertian argues that: Observations and classroom visits are the backbone of supervision. At this stage the teachers teaching in the classroom by implementing the components of the skills that have been agreed on a preliminary meeting. Supervisor observe teachers using observation instruments that have been agreed. In addition to the madrasah supervisor also record objectively the behavior of teachers in teaching, the behavior of students in learning, and teacher interaction in the learning process.

\section{Follow-Up Supervision of Education}

Follow-up is an on-going problem handling the expected completion and are proportional. Any problems that are identified from one execution has taken place, alternative solutions would require a rapid, precise and continuous. This is in line with the essence of the implementation of supervision itself, as stated Burhanuddin that supervision is given to the entire coaching school staff was the one that they can improve the ability to build its better learning situation.

After the supervision is completed, followed by a follow up of the supervision of the teachers who experience difficulties in the learning process. In following up the results of supervision, teaching supervisor can perform in ways guidance to teachers who experience difficulties through discussions, conferences, home visit, discussion and meetings with the teachers, and conduct referrals to other parties. This is in line with the opinion of [9] that "Supervision is an attempt to stimulate, coordinate and guidance is continuous growth of teachers' madrasah, both individually and collectively, to make it more understand and more effective in realizing all the functions of teaching, until thus they are able and more able to participate in a society of modern democracy".

Follow-up supervision of education is one of the main functions of supervision of education and an essential part in an execution supervision. Madrasah supervisors can determine the extent of the supervision program objectives have been achieved and how the process of achievement.

In the process of learning found many difficulties / obstacles by teachers. The results showed that these difficulties include preparing learning tools, developing methods and models of learning, mastery of difficult material, master class management and evaluation of education. Help supervisor for teachers is one of the factors that can increase teachers competencies and solve the problem-faced by 
teachers in the learning process. [10] explains that Attempts to do supervisors in addressing the problems of teachers in the learning process, namely:

a. Hold individual meetings with teachers about the problems they propose;

b. Discuss it with the teacher teaching methods;

c. Guide teachers in shortly arrange and develop learning resources;

d. Those materials to write and develop curriculum;

e. Advised mastery of classroom management;

f. Interpret and summarize the results of the assessment, so get an idea about the possibility of undertaking improvement efforts;

g. Planning a teaching demonstration by the supervisor of teachers who are experts in order to introduce the learning model on new methods of teaching and learning.

Based on the above, madrasah supervisor in West Java, Indonesia has carried out duties in accordance with the authority and responsibility to guide and nurture teachers in order to improve teaching and learning. Supervisor acts as a consultant in overcoming the problems faced by teachers. This is in line with Sahertian, namely: A supervisor is expected to act as a consultant to prepare a dynamic supervision by means of education and training, instruction, counseling and evaluation.

As a follow-up results of supervision, the competence of teachers should be developed through education and training. Education and training is one tool held by each institution for teacher development aimed at increasing skills and knowledge.

Sustainable quality assurance in Madrasah Aliyah (Islamic Senior High School) is a continuous process of the best practices in the management and utilization of human and material resources, facilities, finance, and development of positive corporate culture and strategic supervision of teaching and learning activities for the realization of the sited goals in schools. [11] Sustainable quality assurance in an educational institution is also made possible when every member of the institution contributes his/her quota to the quality process. [12] All these are required to ensure a complete well-rounded education and production of quality students and consistent improvement in Madrasah Aliyah (Islamic Senior High School) system.

The roles of Madrasah supervisor's sustainability in Madrasah Aliyah (Islamic Senior High School) in West-Java Indonesia cannot be over-emphasized. The Madrasah supervisor as a leader of group of principals and teachers in the school system has the function of interacting with the principals and teachers in other to improve the effective management and teaching and learning situation for the students through instructional supervision. Instructional supervision is one processes by which school administrators attempt to achieve acceptable standards performance and results. It is the tool of quality improvement in the school system and a phase school administration which focuses primarily upon the achievement of appropriate expectation of educational system. [13]

School administration involves managing, administering the curriculum and teaching, pastoral care, discipline, assessment evaluation and examinations, resource allocation, costing and forward planning, staff appraisal relationship with the community, use of the practical skills necessary for surviving the policies of organization such as decision-making, negotiation, bargaining, communication, conflict handling, running meetings and so on [14]. All these tasks can be reduced to the following as planning, organizing, directing, supervising, and evaluating the school system. These activities are those of the Madrasah Supervisor who must ensure they are all directed towards efficient and effective teaching and learning in the school so as to be able to produce quality outputs. By implication, the principal of a school is a planner, director, controller, coordinator, organizer, adviser and a problem-solver. [15] The madrasah supervisor is the person on whose shoulders rest the entire administration, success or failure of the school. The madrasah supervisor identifies and set goals and objectives of the school, which of course, must be in line with the national objectives, analyses tasks and share responsibilities of the staff according to specialization and expertise. [16]

Quality education provides students with the knowledge, skills, attitudes and creativity needed to solve problems locally and globally, and actively contributes to the sustainable and democratic development of societies. Thus, our aspirations for quality education must go beyond narrow learning outcomes. Quality education offers, they are far from sufficient. Limiting the outcomes of education may encourage teachers to education had the potential to play a major role in the future realization of a 'vision of sustainability that links economic well-being with respect for cultural diversity, the Earth and its resources'. [17]

The successful implementing the government's policy for the educational development in Madrasah Aliyah they must plan ahead and develop strategies to address the issues. These issues should be addressed at every level, especially the national level, state level and the local level to ensure consistent implementation of the policy across the country. Purposeful deliberation and planning around these issues as well as issues particular to each region will increase the likelihood of successfully implementing the planned programs and reorienting curriculum to achieve sustainability.

1. Management of school admin and finance. In terms of managerial tasks Madrasah Supervisors must perform, they are also expected to teach in order to show an exemplary to other staffs. The demand for greater accountability on the part of principals in the quest for high learner achievement resulted in increased attention being paid to the role of the principal as instructional leader and administrators. Madrasah Supervisor' instructional role needs to be asserted and should be supported by specific training and the principal is the chief executive who can be a responsible and accounting officer who is entrusted with 
the responsibility of controlling the revenue accruing from the school and ensuring judicious utilization of PTA levy collected by the members. In order to raise, fund to complement the efforts of the government, the Madrasah Supervisor can establish a very good rapport with the Parents Teachers Association, Board of Governors, Old Students Association and Non-Governmental Organizations for fund raising activities.

2. Provision and maintenance of physical facilities. Madrasah Supervisor must be fully concerned with the physical environment and other facilities around the school corners. Dilapidated buildings, leaking roofs, abandoned projects, over-grown trees and lawns, dingy and dark buildings that were abandon by the previous government, etc. have demoralizing effects of people, especially the adolescents. [18] As a result, the principals have the responsibilities of ensuring that these facilities are in good shape. Even with the meagre resources at their disposal, they have the responsibility of providing teachers and other instructional staff with necessary resources for effective teaching. [19] Principal is expected to wear many hats, he/she must be a manager, administrator, supervisor, instructional accounting, officer and curriculum leader. According to [20] argues that even though instructional leadership is critical in the realization of effective schools, because it is seldom practiced. He adds that among the many tasks that principals perform, only one-tenth are devoted to providing instructional leadership. The Madrasah Supervisor's instructional leadership role is not given the attention it deserves due some attitudes of some administrators.

3. Madrasah Supervisor as a motivator. According to Ajayi and Oni in Babayemi opined that a Madrasah Supervisor must not only be trained in the act of administration but must be well-acquainted with the principles that guides and control administrative processes effectively. The Madrasah Supervisor owes it a duty to modify the attitude of the staff and motivate them to put in their best at achieving educational goals through effective teaching-learning process. Motivation enhances job performance. [21] A lack of in depth training makes the principals' task difficult, as they are not guided on the curriculum expectations by the Department of Education. Observed that negligence of this area of responsibility by the administrators/principals seems to hinder effective performance of teaching learning activities in the Madrasah Aliyah (Islamic Senior High School) in WestJava Indonesia, that training program for principals on curriculum matters by Madrasah Supervisor are partially at fault for the low priority placed on in-structional leadership by principals so more effort is to be inserted for the general check-up of schools principals.

4. Madrasah Supervisor as a curriculum instructional supervisor. The functions of the Madrasah Supervisor as a supervisor includes obtaining and making available materials for teachers in all educational information, visiting classrooms often to observe his/her teachers teaching; basic inspection/supervision of teachers lesson notes and class registers, diaries and teaching aids and offering them professional advice for their proper improvement of teaching and learning in the system where as he can act as a change facilitator. [22] viewed that Madrasah Supervisors must possess a wide array of competencies in order to lead schools effectively towards the accomplishment of educational goals, which has led to changing expectations of what leaders need to know and must be able to do.

Different competencies such as capacity building, vision building and/or a team building required of Madrasah Supervisor to cope with the changing demands of the education sector have been suggested by experts and researchers comes to efforts to improve the quality of school, the principal is the critical person in making change to occur. According to Uyanga, since a Madrasah Aliyah (Islamic Senior High School) is known to be an instrument of change and reforms in the society, the Madrasah Supervisor is said to be the pivot of such reforms and changes. This responsibility is very obligatory and the Madrasah Supervisors are expected to deploy the managerial skills in adapting to this change and effecting it in the school system. The Madrasah Supervisor is the key-supporting agent for change.

According to [23] agreed that the Parents Teachers Association (PTA) or Komite Madrasah assists in improving the enrolment of the schools in their communities; helps in maintaining disciplines in the schools; ensure smooth coexistence, understanding and cooperation between the school and the community. Adewumi in Oniyangi also submitted that the PTA helps in sensitization and mobilization of parents on enrolment attendance and retention of their children or wards in schools. Besides, [24] also reported that the PTA complements governments' efforts in the provision and maintenance of infrastructures in the schools.

These and many more suggestion that the PTA has been participating on matter affecting education in Madrasah Aliyah di West-Java Indonesia. It is to be noted however, that virtually all the Madrasah Aliyah (Islamic Senior High School) in the country has the PTA in place. Despite the laudable roles of the PTA in Madrasah Aliyah (Islamic Senior High School) it appears that the problems of the schools still thrive. It therefore presupposes that the roles of the PTA can be strengthened in order to enhance better community participation in the schools.

Discipline which involves self-control training of the mind of body self-respect to rules and regulation of authority should be the watch word for teachers in their job performance. Thru it most discipline is one of the important criteria for teaching worth. The role of the Madrasah Supervisor is to facilitate the implementation of the various learning programs aimed at improving the learning situation. Teachers whether new or old on the job need necessary support in implementing the instructional programs. The Madrasah Supervisors need to provide this support to principals and teachers, they have to be involved in the 
implementation of instructional programs by overseeing what teachers are doing with the students. A good The Madrasah Supervisor should devote himself to supervise the teaching learning processes in his school. The Madrasah Supervisor as the supervisor is the one who oversees the activities of teachers and other workers in the school system to ensure that they conform to the generally accepted principles and practice of education.

\section{CONCLUSION}

In the school system, the responsibility of coordinating these activities normally falls on the principal. The principal is a professional leader who holds the key position in the programed of instruction improvement through supervision of instruction. If the teachers are not well supervised effectiveness in instruction, it will be adversely affected and the instructional purposes may not be well realized. But, negligence in the improvement of instruction through improper supervision by the principal can go on indefinitely without being detected. This may lead to low quality of instruction and invariably, teachers' lack of commitment to job.

The Madrasah Supervisor is a leader counsellor, a guide, a psychologist, the chief communicator and the teacher of teachers. The question one would ask at this point is whether the principals as instructional supervisors and administrative heads do perform the roles and functions associated to such titles for the overall process of education system. It is often difficult for a principal to oversee every teacher in a school especially now that the school population is extremely large. To ease his supervisory roles, the principal should delegate some duties to the vice principal and senior teachers within the school.

A supervisor is a person appointed to take care or in charge of a group of people to ensure that work is carried out satisfactorily. He is responsible for achieving the objectives of the organization within limits of his authority and for maintaining a good quality of person. The person in the best position to perform these responsibilities in the secondary school system is the principal. The following explanations show that principals play numerous roles and perform various functions in the course of his work. He works with the teachers and gives them advice and encouragement, coordinates the various parts of the school activities in an effective environment conducive for learning. $\mathrm{He}$ is a protector of teachers and services as a buffer between them and the unreasonable demands and pressures from the community. In most opinion, all Madrasah Supervisors should include the followings in their supervisory tasks.

a) Creating of conducive environment where creating and learning takes place for both teachers and students;

b) Provision of leadership in program development and fostering of team spirit among teachers;

c) The provision of leadership in the development of the school into an informal organization, where problems and decisions are debated with a view to arriving at rational solutions; d) Integration of organization goals to community goals; and,

e) The introduction of new teacher's performance evaluation, primarily for the development of appropriate skills for the achievement of the goals of the education system.

The motivational advantages of madrasah supervisors' supervisory behavior on teachers' performance cannot be overemphasized, it involves discipline and dedication. Discipline involves self-control, and respect for others, disciplined teacher is guided in his behavior, moral and social principles and does what is right and good. [25] It is true that discipline is one of the important criteria in knowing the worth of a teacher, because in Nigerian schools, the problem of discipline is a cankerworm that has eaten deep into the fabric of the Nigerian society.

According to [26] views that the important of supervision that it requires/urges school leaders to see supervision not as a series of tasks but views it as a sustainable model of cultivation which relates some aspects that can be viewed for the improvement of the educational sector and effective cultures establish more and more progressive interactions in which it demands real processes which will yield both good ideas and social cohesion in the system.

Based on the literature, we may able to conclude that the study was made in order to improve instructional supervision for the achievement of the set educational goals in Madrasah Aliyah (Islamic Senior High School). The Madrasah Supervisors should provide adequate instructional materials and facilities through Parents-Teachers Associations, (PTA), Old boys Associations, Non-Governmental Organizations (NGOs), Communities, Philanthropists and other Development Partners, to enhance effective teaching and learning processes in Madrasah Aliyah (Islamic Senior High School).

The Madrasah Supervisors should provide constant and adequate feedback to the teachers on their instructional task performance to ensure periodic review and facilitate further improvement in the teaching-learning process in Madrasah Aliyah (Islamic Senior High School). Madrasah Supervisors should collaborate with relevant stakeholders to promote capacity development of teachers through intensive and regular in-house seminar/workshop to improve knowledge, pedagogical skills and competence of teachers in various subjects, and improvisation of instructional materials to enhance teaching-learning process in Madrasah Aliyah (Islamic Senior High School).

Government and professional bodies in the education sector should organize periodic capacity development workshops for educational managers (supervisors) on institutional management and instructional supervision to improve the quality of teaching and learning processes in Madrasah Aliyah (Islamic Senior High School) West Java Indonesia. All the stakeholders in the education sector should collaborate to organize annual education summit for comprehensive review and assessment of the degree of success in school supervision with a view to producing the 
desired outputs and achieving the overall educational objectives to ensure sustainable improvement in institutional management and curriculum delivery in Madrasah Aliyah (Islamic Senior High School).

The Madrasah Supervisor should occupy a central position in educational reform. Owing to challenging circumstances and changing demands in the education sector, they are expected to be structured issues and curriculum changes need to be provided. This will ensure that Madrasah Supervisors are conversant with the curriculum changes, Changes in the education sector are inevitable due to the dynamic nature of knowledge and changes in technology and the appropriate mechanisms need to be put in place to ensure that anticipated change is realized and that those affected by change are assisted to experience a swift transition and proper adjustment of the entire system.

\section{References}

[1] Razik, T.A. \& Swanson, C.D. (2001). Fundamental concepts of educational leadership. Upper Saddle River, NJ: Merrill/Prentice Hall.

[2] Fullan, M. (1995). The school as a learning organization. Theory into Practice, 34(4), 230-235.

[3] Maryono (2011). Dasar-dasar dan Teknik menjadi Supervisor Pendidikan. Yogyakarta: Ar-Ruzz Media.

[4] Soetisna, Otoeng (1983). Administrasi Pendidikan.

[5] Merriam, S. B. (2001). Qualitatif Research and Case Study Application in Education: Revised and Expanded from case study research in education. San Francisco: Jossey-Bass.

[6] Burhanuddin, Y., (2007). Administrasi Pendidikan. Bandung: Pustaka Setia.

[7] Siahaan, A., (2006). Manajemen Pengawas Pendidikan. Jakarta: Quantum Teaching.

[8] Sahertian, P., (2008). Konsep Dasar dan Teknik Supervisi Pendidikan dalam Pengembangan Sumber Daya Manusia. Jakarta: Rineka Cipta.

[9] Sagala, S., (2008). Administrasi Pendidikan Berkompetensi. Bandung: Alfa-beta.

[10] Purwanto, M.N., (2007). Administrasi dan Supervisi Pendidikan. Bandung: Remaja Rosdakarya.

[11] Ayeni, A. J. and Akinola, O. B. (2010), Influence of principals 'leadership styles and motivation of teachers on quality assurance in secondary school: A case study of Ondo State. Ife Journal of Theory and Research in Education, $I I(1 \& 2), 167-170$.

[12] Zuhari, A., \& Suparman, A. (2002). Managing quality and accessibility in open and distance learning. In Dkshit, H. P. (et. al). Access and equity (p. 262). New Delhi: Kogan Page
[13] Peretomode, V. F. (2004). Principles and Techniques of Instructional Supervision. In: Peretomode, VF (ed) Introduction to Educational Administration, and Supervision. Lagos: : Joja Education Research and Publishers Ltd.

[14] Okereke, C. (2008).Quality assurance in teacher selection among private secondary schools in Owerri municipal, Imo State for effective implementation of the UBE. Journal of Curriculum Organization for Nigeria., 37-44.

[15] Maduabum, M. A. (2002). Occupational stress factors among secondary school principals in Abia State, Nigeria. International Journal of Educational Planning and Administration. 1(1): 17-27.

[16] Uyanga, R. E. (2008). The principal and education reform agenda of the Nigerian economic empowerment development strategy (NEEDS) and the millennium developmental goals (MDGs). In P.

[17] UNESCO (2007). The UN Decade for Education for Sustainable Development (DESD 2005-2014): the first two years. UNESCO, Paris.

[18] Obidoa, Elom, S. O., O., Attah, C. A. and Ezeanyika, L. U. S. (2006). Effect of intervention with dietary supplements on the prostate-specific antigen (PSA) levels of prostate patients in a Nigerian population. J. Visual and Health Sciences 8(2), 73-82.

[19] Babayemi, A. (2006). Principalship. In J. B. Babalola, A. O. Ayeni, S. O. Adedeji, A. A. Suleiman and M. O. Arikewuyo (eds) Educational Management: Thoughts and Practice. Ibadan: Codat Publications. 242261.

[20] Phillips JA. (2012). Manager-Administrator or Instructional Leader: Shift Role of the Principal. From <http: //www.learningdomain.com/PrincipalInstructLeader.htm> (Retrieved March 14, 2016)

[21] Ajayi, I. A., \& Ekundayo, H. T. (2010). Contemporary Issues in Educational Management. Lagos:Bolabay

[22] Marlow S, Minehira N (2011). Principals as Curriculum Leaders: New Perspectives for the Twenty-first Century.from http:www.pre.org/product/products//Curriculum. html> (Retrieved April 22, 2016).

[23] Oniyangi, S.O (2008): Teachers' perception of pupils involvement in provision of teaching materials as predicator of internalized knowledge achievement in health education in secondary school in Ilorin Metropolis.West African Journal of physical and Health Education. 12 (262-275). A Publication of the West Africa Journal of Physical and Health Education (WAJOPHE) Department of Human Kinetics and Health Education, University of Ibadan, Nigeria.

[24] Abdullahi, S. U. (1996). Parent teacher association as an instrument of community participation in education. Retrieved from http://www.zedang.org/agm lectures/4The.pdf on 31/03/2016

[25] Edem, D A (1998). Introduction to Educational Administration in Nigeria. Ibadan: Spectrum Books Ltd.

[26] Daresh, J. (2007). Supervision as Proactive Leadership. (4th Ed.) Long Grove, IL: Waveland Press 